\title{
Impact of nitrogen atmosphere on sintering of alumina ceramics
}

Judit CsÁnYI TamÁsnÉ - University of Miskolc - femjuci@gold.uni-miskolc.hu

LÁSzLó A. GöMzE =Department of Ceramics and Silicate Engineering - femgomze@gold.uni-miskolc.hu

A nitrogén atmoszféra hatása az alumínium-oxidkerámiák zsugorítására

Hagyományos szennyezettségú $\mathrm{Al}_{2} \mathrm{O}_{3}$ porok semleges nitrogén gázközegben történó zsugorítása során az $\alpha-\mathrm{Al}_{2} \mathrm{O}_{3}$ mellett egy új fázis is megjelenik, amely javítja a kerámia mechanikai jellemzóit.

A tanulmány ismerteti a zsugorított minta mikroszerkezetét, amelyet SEM, EDAX s RTG-diffrakciós módszerrel vizsgáltak. A vizsgálatok alapján megállapítható, hogy a hốkezelés egy új fázis, az ALONC kialakulásához vezet.

\section{Introduction}

Several industries, like electronics have been using products made of very high purity $(>99,9 \%) \mathrm{Al}_{2} \mathrm{O}_{3}$ powder because of their excellent mechanical and electrical properties. These products are mainly produced by dry pressing, sintering. In order to achieve the special mechanical features the use of the right technology is as important as the selection of the raw material.

Many studies are investigating the sintering behaviour of alumina, its microstructure $[1,2,3]$. Our work until now has focused on obtaining deeper knowledge about these properties and on the description of mechanical characteristics of alumina, heat treated in nitrogen atmosphere [4].

Heat treatment in nitrogen gas is a well-known technology for steels, resulting the increase of surface hardness of steels, their wear resistance, resistance to repeated use and corrosion. In this procedure alloy elements - carbon, nitrogen, silicon, and aluminum - are entered into the surface layer of the steel by diffusion - modifying, improving its mechanical and chemical properties $[5,6,7]$.

The purpose of the present study is to present the results of heat treatment in nitrogen inert gas of alumina ceramics, and to discover the changes in the microstructure of the surface layer.

According to the literature several authors are dealing with the use of nitrogen atmosphere by adding other additives (AIN) $[8,9,10,11]$. During the sintering the nitrogen - entered in the form of gas or solid substance (AlN) - and its reaction with the rigid, solid material produces a new substance, a very tough material, keeping its mechanical properties. The result of heat treatment in nitrogen inert gas is the production of AlN and $\mathrm{AlON}$, besides $\mathrm{Al}_{2} \mathrm{O}_{3}$. $\boldsymbol{A l l}$ has several excellent properties, its thermal conductivity, specific resistance is high, the dielectric constant is moderately low. AlN cannot be found in the nature. It can be produced by nitridation of metal aluminum powder, or by the carbothermic reaction of alumina powder [12]. AlON is a kind of polycrystalline material, the structure of which is just the inverse of spinel. It is a glass-like, poreless material of great hardness, but with low heat conductivity. Among the methods to be used for the production of alumina nitride phase the most popular are simultaneous reduction and nitridation of $\mathrm{Al}_{2} \mathrm{O}_{3}$, oxynitridation of metal aluminum during firing, its gas phase reaction with $\mathrm{AlCl}_{3}$, direct reaction between $\mathrm{Al}_{2} \mathrm{O}_{3}$ and $\mathrm{AlN}$ [9].
Tamásné Csányi Judit

Anyagmérnöki diplomát szerzett 2001 nyarán a Miskolci Egyetem Anyag- és Kohómérnöki Karán. Tanulmányait doktoranduszként a jelenlegi Kerámia- és Szilikátmérnöki Tanszéken folytatta 2001-2004 között. 2003-ban tanulmányi ösztöndíjat nyert, így az Epcos Deutchlandsberg AG elektronikai vállalatnál kerámiafilmek fémezését tanulmányozta. 2004 óta, Szombathelyen az Epcos Elektronikai Alkatrész Kft. fejlesztômérnökeként dolgozik. 2007-ben sikeresen megvédte mühelyvitáját.

Dr. Gömze A. László 1973-ban szerzett gépészmérnöki oklevelet a Moszkvai Épitômérnöki Egyetemen. Szilikátvegyész oklevelét 1979-ben kapta a Mengyelejev Kémia-technológiák Egyetemen. 1985-ben a múszaki tudományok kandidátusa - kitüntetéssel. Szakmai pályafutását az Épületkerámia-ipari Vállalatnál kezdte, ahol részt vett a Kerámia Téglagyár, a Padlólap II. és az új Ôrbottyán II. Téglagyár tervezésében. 1977-ben már a KEVITERV Egyedi Gépek és Létesítmények tervezõ osztályát irányította. Még ebben az évben tanársegéd lett Szaladnya Professzor mellett a Miskolci Egyetemen. Ugyanitt 1999-tôl a Kerámia- és Szilikátmérnöki Tanszék vezetôje. Több szabadalom és találmány szerzôje. Hazai és külföldi publikációjának száma meghaladja a 200-at.

According to the literature the reaction of $\mathrm{Al}_{2} \mathrm{O}_{3}$ and $\mathrm{AlN}$ produces AlON phase above $1650{ }^{\circ} \mathrm{C}$, which can be made by plasma spraying, adding AlN, sintered in nitrogen gas.

In the plasma spraying technology first the $\mathrm{Al}_{2} \mathrm{O}_{3} / \mathrm{AlN}$ composite powder is sintered in $\mathrm{Ar} / \mathrm{N}_{2}$ plasma $(\approx 10000 \mathrm{~K})$, which is direct nitridation of alumina. With this method cubic lattice AlN can be produced, containing $\mathrm{N}$ - and $\mathrm{O}$-ions. The AlN and $\gamma-\mathrm{Al}_{2} \mathrm{O}_{3}$ content of the thus produced material is growing compared to the $\mathrm{AlN}$ and $\mathrm{Al}_{2} \mathrm{O}_{3}$ content of the original (starting) material. Thus further heat treatment is required in nitrogen gas at $800-1200{ }^{\circ} \mathrm{C}$ for 2 hours with temperature holding. As a result of later heat treatment the AlN will be of hexagonal lattice, the AlN quantity will increase, but the $\gamma-\mathrm{Al}_{2} \mathrm{O}_{3}$ content will decrease. [13]

The quantity of $\mathrm{AlN}$ added to $\mathrm{Al}_{2} \mathrm{O}_{3}$ and the sintering temperature influence significantly the material microstructure.

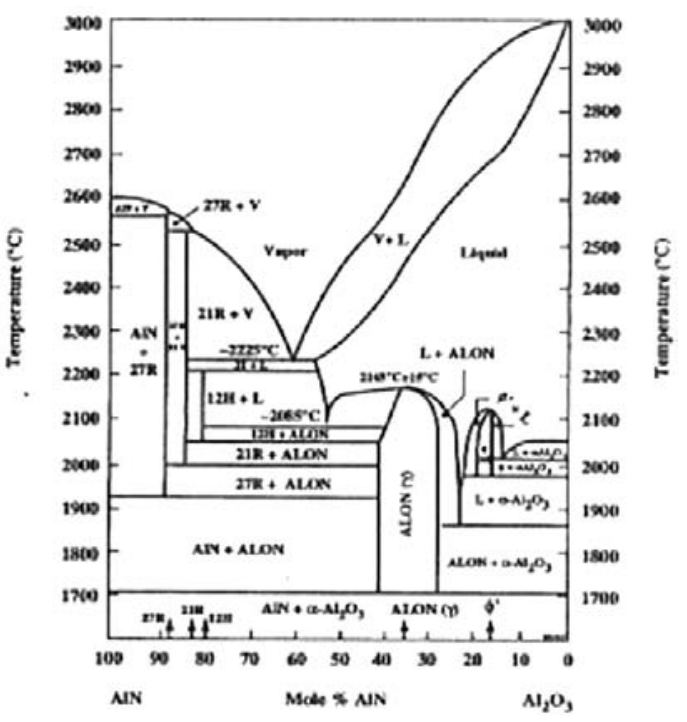

Fig. 1. Phase diagram of $\mathrm{AlN}-\mathrm{Al}_{2} \mathrm{O}_{3}$

1. ábra $\mathrm{AlN}-\mathrm{Al}_{2} \mathrm{O}_{3}$ fázisdiagram

(Taken from: Allen M. Alper: Phase Diagrams in Advanced Ceramics 29. [14]) 
During sintering in nitrogen gas homogenous microstructure is achieved with lower $(<10 \mathrm{~mol} \%) \mathrm{AlN}$ content, AION appears on the contact surface of alumina. At higher AlN content the produced $\mathrm{AlON}$ is around the grain boundary of alumina.

McCauley and Corbin sintered in situ the $\mathrm{AlN}$ and $\mathrm{Al}_{2} \mathrm{O}_{3}$ powders, grinded together. Several combinations of production parameters were discovered. As shown by Figure 1 the liquid phase can be found in a very narrow stripe of the solid phase at high temperature. The results of sintering at $1975^{\circ} \mathrm{C}$ are grain porosities, but the higher temperature $\left(2025^{\circ} \mathrm{C}\right)$ produces much less porosity and ALON.

The method was improved later, the starting powder is $0,5 \mu \mathrm{m}$ and smaller grain size distribution ALON powder, formed by preliminary reactions [15]. Reaction of the starting powder:

$$
\mathrm{Al}_{2} \mathrm{O}_{3(\mathrm{~s})}+\mathrm{C}_{(\mathrm{s})}+\mathrm{N}_{2(\mathrm{~g})} \geq \mathrm{ALON}_{(\mathrm{s})}+\mathrm{CO}_{(\mathrm{g})} \text { (1) }
$$

Tabary, Servant and Alary observed, that carbon is present in two forms. On the one hand in the form of graphite, not entering into reaction during melting, on the other in a form embedded into separations, becoming an $\mathbf{A l}-\mathbf{O}-\mathbf{N}-\mathrm{C}$ quaternary system.

Figure 2 shows the phase structure of „AlONC” in Mol quantity along the line connecting points a $\mathrm{P}_{1}\left(25 \% \mathrm{Al}_{2} \mathrm{O}_{3}-75 \% \mathrm{AlN}\right)$ and $\mathrm{P}_{2}\left(60 \% \mathrm{Al}_{2} \mathrm{O}_{3}-20 \% \mathrm{AlN}-20 \% \mathrm{Al}_{4} \mathrm{C}_{3}\right)$. The intersection point of $\mathrm{Al}_{2} \mathrm{O}_{3}-\mathrm{Al}_{4} \mathrm{C}_{3}$ section can be $26,5 \mathrm{~mol} \% \mathrm{Al}_{4} \mathrm{C}_{3}$, not following the literature value. Thus $\mathrm{Al}_{4} \mathrm{O}_{4} \mathrm{C}$ can be found at $20 \mathrm{~mol} \% \mathrm{Al}_{4} \mathrm{C}_{3}$ and $\mathrm{Al}_{2} \mathrm{OC}$, and also at $50 \mathrm{~mol} \% \mathrm{Al}_{4} \mathrm{C}_{3}$. Three dominant $\mathrm{AlN}$ based compositions can be distinguished. The general form is AlN$\mathrm{Al}_{2} \mathrm{O}_{3}$ in pseudo-binary system it is $\mathrm{Al}_{\mathrm{n}} \mathrm{O}_{3} \mathrm{~N}_{(\mathrm{n}-2)}$. In the $\mathrm{Al}_{2} \mathrm{O}_{3}$ $\mathrm{Al}_{4} \mathrm{C}_{3}$ pseudo-binary phase this formula becomes $\mathrm{Al}_{(\mathrm{x}+4)} \mathrm{O}_{(1.5 \mathrm{x})} \mathrm{C}_{3}$, where $x=8 ; 6 ; 5 ; 4,4$ and 4 ; and the $\mathrm{M} / \mathrm{X}=\mathrm{n} / \mathrm{n}+1$ ratio is equal to $4 / 5,5 / 6,6 / 7,7 / 8$, and $8 / 9$, where $\mathrm{M}=\left(\mathrm{n}_{\mathrm{Al}}\right)$ and $\mathrm{X}=\left(\mathrm{n}_{\mathrm{O}}+\mathrm{n}_{\mathrm{C}}\right) \cdot[16]$

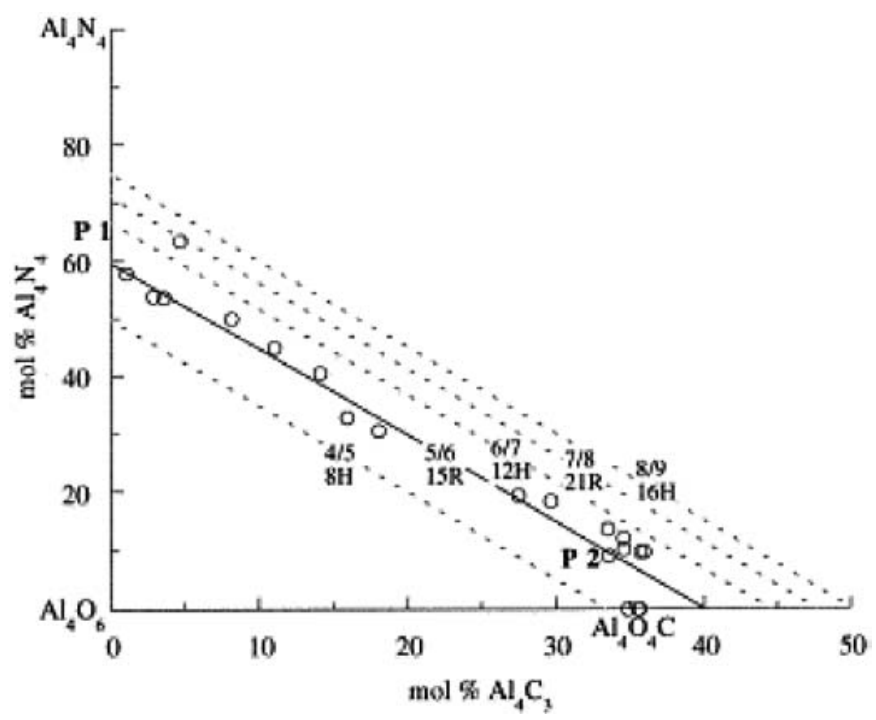

Fig. 2. Content of AlONC phase in $\mathrm{Al}_{4} \mathrm{O}_{6}-\mathrm{Al}_{4} \mathrm{~N}_{4}-\mathrm{Al}_{4} \mathrm{C}_{3}$ pseudo-terner system

2. ábra $\mathrm{Az}$ „AlONC” fázis összetétele az $\mathrm{Al}_{4} \mathrm{O}_{6}-\mathrm{Al}_{4} \mathrm{~N}_{4}-\mathrm{Al}_{4} \mathrm{C}_{3}$ pszeudo-ternér rendszerben

(Taken from: Tabary, Servant, Alary: Journal of the European Ceramic Society p. 1918)

\section{Test conditions}

During the experiment the sintering abilities of alumina powders of different purity were investigated with the use of nitrogen gas. Table 1 shows the compound of the powders applied by us, according to the datasheet of the manufacturer partly 3\% polyvinyl-ester, polyvinyl-ethanol, polyvinyl-glycol, partly $6 \%$ magnesium-silicate and 5\% alkali-earth metal carbonate are needed to the preparation of pressing powders. Of the Kreutz SPG 95 and Alcoa CT 3000 SDP alumina powder, shown in Table 1. annular specimen were made with bilateral pressing by the mechanical press of Mikeron $\mathrm{Kft}$, where the diameter of the pressing tool dowel was $34,6 \mathrm{~mm}$, the diameter of the housing was $47,7 \mathrm{~mm}$.

\begin{tabular}{lcc} 
Compound & Kreutz SPG 95 & Alcoa CT 3000 SDP \\
$\mathbf{A l}_{2} \mathbf{O}_{3}$ & $\approx 95 \%$ & $99,7 \%$ \\
\hline $\mathbf{S i O}_{\mathbf{2}}$ & $2,2 \%$ & $0,02 \%$ \\
\hline $\mathbf{M g O}$ & $1,40 \%$ & $0,1 \%$ \\
\hline $\mathbf{C a O}$ & $1,10 \%$ & $0,03 \%$ \\
\hline $\mathbf{N a}_{\mathbf{2}} \mathbf{O}$ & $<0,2 \%$ & $0,08 \%$ \\
\hline $\mathbf{F e}_{\mathbf{2}} \mathbf{O}_{\mathbf{3}}$ & $<0,3 \%$ & $0,02 \%$ \\
\hline \hline
\end{tabular}

Table 1. Content of applied pressing powder

1. táblázat A felhasznált préspor összetétele

Part of the raw specimen was pre-sintered in normal way, at $1250{ }^{\circ} \mathrm{C}$, the remaining part in nitrogen gas at $1420^{\circ} \mathrm{C}$ in composition-type resistor furnace. The pre-sintered semi-finished product was sintered at $1640{ }^{\circ} \mathrm{C}$ in Nabel HT128 type furnace of Mikeron Kft.

The additive content of pressing powders was tested by DSCequipment. Microstructure of the burnt specimen was tested by SEM, EDAX and X-ray diffraction meter.

\section{Results}

The DSC diagram of $\mathrm{Al}_{2} \mathrm{O}_{3}$ powders was taken into account to the establishment of test conditions (Figure 3 ). The investigation confirmed that in the presence of oxygen the organic materials begin to evaporate at $240-250^{\circ} \mathrm{C}$ out of the 95 and $99,7 \%$ content

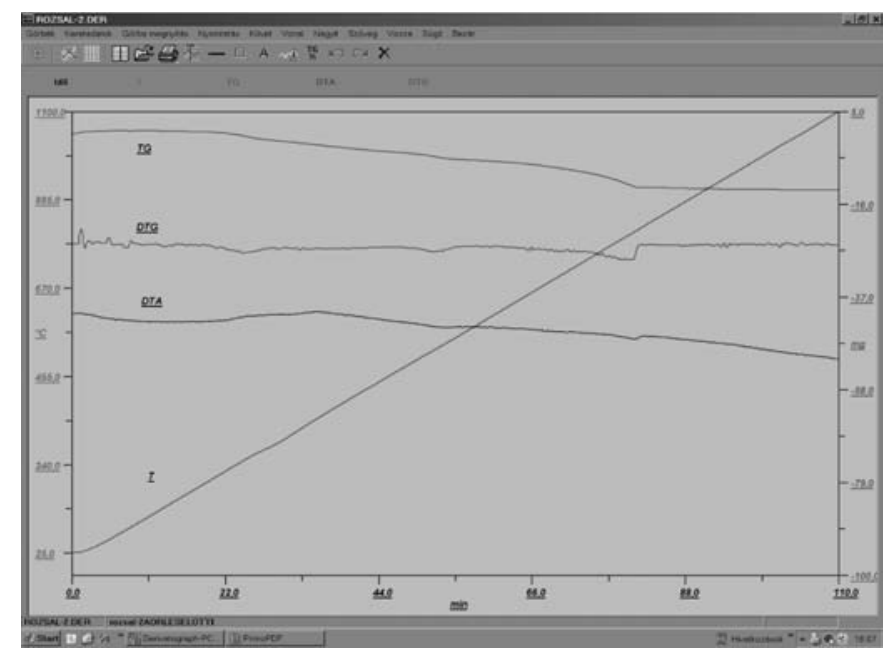

Fig. 3. DSC analysis of $95 \% \mathrm{Al}_{2} \mathrm{O}_{3}$

3. ábra $95 \%$ tartalmú $\mathrm{Al}_{2} \mathrm{O}_{3}$ kerámia DSC vizsgálata 
pressing powder. The evaporation process lasts nearly until the attainment of $800^{\circ} \mathrm{C}$. Thus in our test during the pre-sintering process the $\mathrm{N}_{2}$ gas had been continuously flown from $500^{\circ} \mathrm{C}$. It is known that with the reduction of oxygen the dissociation of organic materials cannot be completed, thus some percentage carbon is left in the biscuit baked, sintered ceramics [17].

Fracture surface of samples pre-sintered in nitrogen gas and burnt in normal atmosphere (Figure 4) was tested, analyzed.

It can be seen on Figure 4, that in the external layer of the specimen a new, characteristically different - form the traditionally sintered $\mathrm{Al}_{2} \mathrm{O}_{3}$ ceramic - structure had developed.
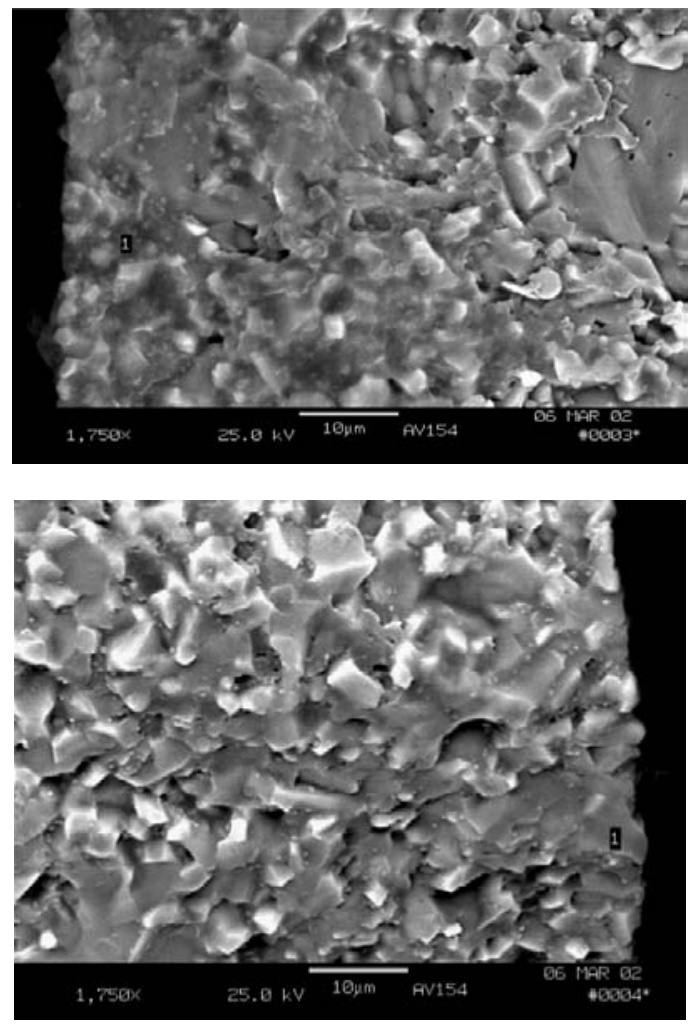

Fig. 4. Fracure surface of $\mathrm{N} 2$ heat treated, sintered $\mathrm{Al}_{2} \mathrm{O}_{3}$ by SEM (95\% $\mathrm{Al}_{2} \mathrm{O}_{3}$; pressure: $177,1 \mathrm{MPa}$; max time of pressure: $15 \mathrm{~s}$ )

4. ábra Nitrogén atmoszférában hökezelt próbatestek töretfelületének SEM felvétele (95\%-os $\mathrm{Al} O \mathrm{O}$, sajtolónyomás: 177,1 MPa, a sajtolónyomás max. hatóideje: $15 s)$

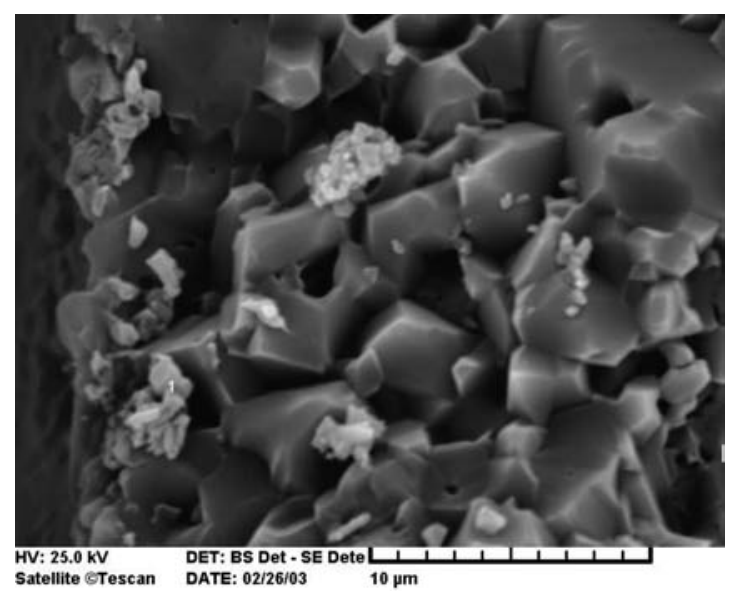

Fig. 5. Fracure surface of $\mathrm{N}_{2}$ heat treated, sintered $\mathrm{Al}_{2} \mathrm{O}_{3}$ by EDX

5. ábra Nitrogén atmoszférában hökezelt próbatestek töretfelületének EDX felvétele

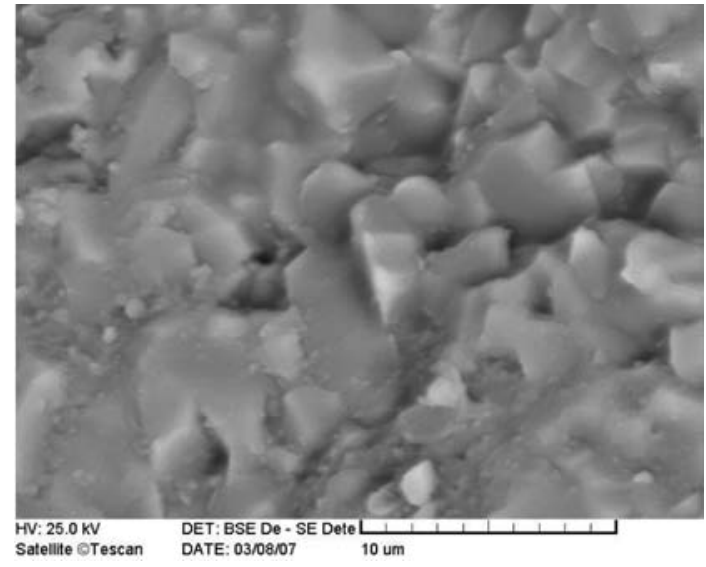

Fig. 6a. Fracure surface of $\mathrm{N}_{2}$ heat treated, sintered $95 \% \mathrm{Al}_{2} \mathrm{O}_{3}$

6a. ábra Nitrogén védögázban elöégetett $95 \% \mathrm{Al}_{2} \mathrm{O}_{3}$ töretfelületének felvétele a felszín közelében

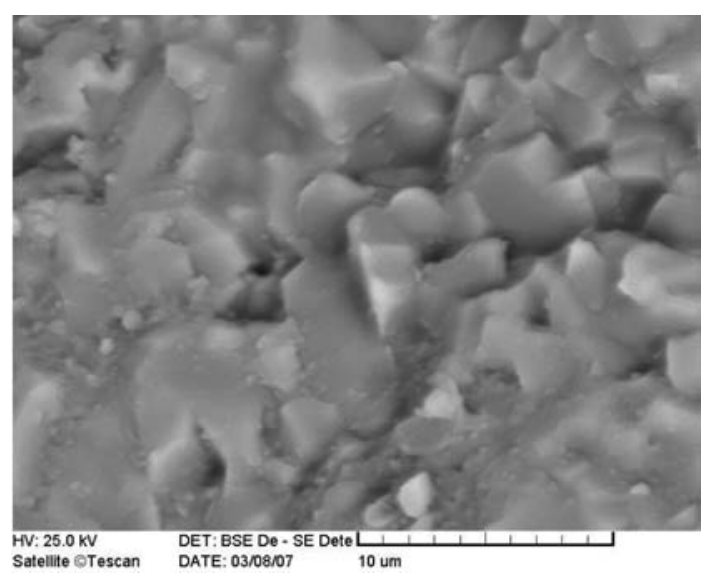

Fig. 6b. Innert part at fracure surface of $\mathrm{N}_{2}$ heat treated, sintered $95 \% \mathrm{Al}_{2} \mathrm{O}_{3}$ 6b. ábra $\mathrm{N}_{2}$ védögázban elóégetett $95 \% \mathrm{Al}_{2} \mathrm{O}_{3}$ kerámia belsö részének töretfelülete

Figure 5 shows the spectrum of the average composition of the fracture surface. The picture shows that besides aluminum and oxygen, carbon has also appeared.

Figure 6 shows outer layer of the fracture surface of $95 \%$ $\mathrm{Al}_{2} \mathrm{O}_{3}$ ceramic with $\mathrm{M}=10000 \mathrm{X}$ enlargement. Square granules typical of alumina, as well as the great number of tiny granules left out of consideration until now were observed! The tiny granules are only of $0,1-1 \mu \mathrm{m}$ size. Here the traces of a new phase in the middle of the specimen could be seen.

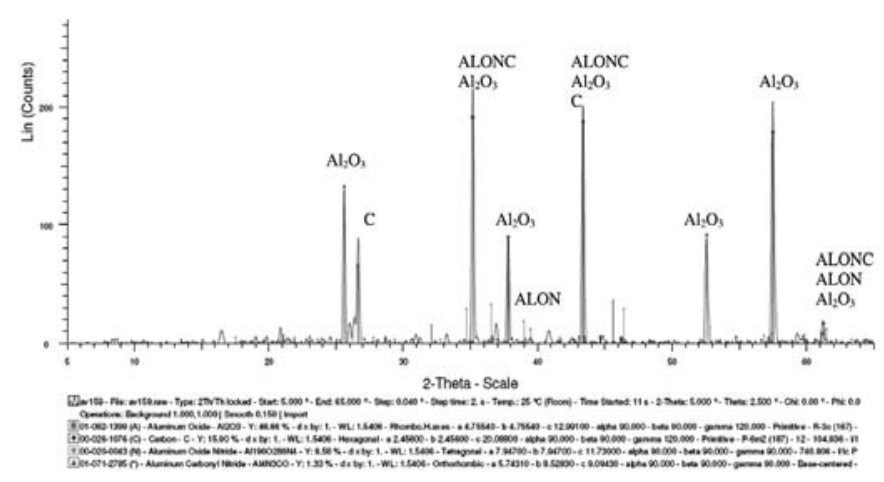

Fig. 7. Roentgen diffraction of ceramic sample

7. ábra A vizsgált minta röntgendiffrakciós felvétele 
The structure of ceramics heat treated in nitrogen gas was determined on the basis of X-ray diffraction test. The results are shown on Figure 7. It can be seen that next to the tips of $\mathrm{Al}_{2} \mathrm{O}_{3}$ carbon in crystal form, and also $\mathrm{Al}_{4} \mathrm{~N}_{3} \mathrm{CO}$ (ALONC) had appeared. Most of the ALON tips fit to the diffractogram, its presence is still not completely proved. The results of our experiments are significant, since we have proved, that already at relatively low temperature ALONC is produced in alumina ceramics of traditional „contamination” pre-sintered in nitrogen gas.

Observations of Tabary, Servant and Alary support our findings, that carbon is present in two forms. Once in the form of graphite, which does not enter into reaction during melting, and in the form of $\mathbf{A l}-\mathrm{O}-\mathrm{N}-\mathrm{C}$ quaternary system.

\section{Conclusion}

1. Our tests clearly confirm that during sintering of $\mathrm{Al}_{2} \mathrm{O}_{3}$ nitrogen gas exercises similarly positive impact on the material structure and mechanical behaviour of the ceramics, as is the case with nitridating, or carbo-nitridating of steel alloys. It was proved by SEM photos that close to the surface of the sintered body $0,1 \mu \mathrm{m}$ granules develop and distribute in large volume in the material structure, owing to the presence of which the water and gas compactness and mechanical stability of the material system is significantly increasing.

2. On the basis of the tests it can be stated, that with the use of the right production technology (pressing, sintering atmosphere, sintering temperature) excellent quality products can be produced of the $92-99,7 \% \mathrm{Al}_{2} \mathrm{O}_{3}$-content basic materials of traditional „contamination”, which had only be produced until now of the 4 th and 5 th generation high purity $\mathrm{Al}_{2} \mathrm{O}_{3}$.

\section{References}

[1] Shui, A. - Kato, Z. - Tanaka, S. - Uchida, N. - Uematshu, K.: Development of anisotropic microstructure in uniaxially pressed alumina compacts. Journal of the European Ceramic Society 22 (2002) 1217-1223

[2] Shui, A. - Saito, M. - Uchida, N. - Uematsu, K.: Origin of shrinkage anisotropy during sintering for uniaxially pressed alumina compacts. Powder Technology 127 (2002) 9-18

[3] Sathiyakumar, M. - Gnanam, F. D.: Influence of additives on density, microstructure and mechanical properties of alumina. Journal of Materials Processing Technology 133 (2003) 282-286

[4] Csányi, J. - Gömze,A. L.- Kövér, Zs. I.: Néhány nagytisztaságú $\mathrm{Al}_{2} \mathrm{O}_{3}$ müszaki kerámia hajlitószilárdsági vizsgálata. Építőanyag, 56. évf. 3. szám (2004.) pp.101-107

[5] Zorkóczy B.: Metallográfia és anyagvizsgálat. Tankönyvkiadó, Budapest 1968.

[6] Verő J.- Káldor M.: Fémtan. Tankönyvkiadó, Budapest, 1977.

[7] Tóth, T.: Fémtan II-III. Nemzeti Tankönyvkiadó, 1993.

[8] Tabary, P. - Servant, C. - Alary, J. A.: Effects of a low amount of $C$ on the phase transformations in the $\mathrm{AlN}-\mathrm{Al}_{2} \mathrm{O}_{3}$ pseudo-binary system. Journal of the European Ceramic Society, Vol. 20. (2000) pp. 1915-1921

[9] Kim, Y. W. - Park, H. C. - Lee, Y. B. - Oh, K. D. - Stevens, R.: Reaction sintering and microstructural development in the system $\mathrm{Al}_{2} \mathrm{O}_{3}$-AlN. Journal of the European Ceramic Society, Vol. 21 (2001) pp. 2383-2391

[10] Maghsoudipour, A. - Moztarzadeh, F. - Saremi, M. - Heinrich, J. G.: Oxidation behaviour of $\mathrm{AlN}-\mathrm{Al}_{2} \mathrm{O}_{3}$ composites. Ceramics International 30 (2004) pp. 773-783

[11] Nivot, C. - Valdivieso, F. - Goeuriot, P.: Nitrogen pressure effects on nonisothermal alumina sintering. Journal of the European Ceramic Society Vol.26 (2006) pp. 9-15

[12] Okasa, T. - Toriyama, M. - Kanzaki, S.: Journal of European Ceramic Society. Vol. 20, 2000. pp.783-787

[13] Cao, L. H. - Khor, K. A. - Fu, L. - Boey, F.: Journal of European Ceramic Society. Vol. 89-90, 1999. pp.392-398

[14] A. M. Alper: Phase Diagrams in Advanced Ceramics. Academic Press, Inc., London, 1995. pp.15-83.

[15] Hongyu, G. - Yansheng, Y. - Aiju, L. - Yingcai, L. - Yuhua, Z. Chunsheng, L.: Materials Research. Bulletin, Vol. 37, 2002. pp.1603-1611

[16] Tabary, P. - Servant, C. - Alary, J. A: Journal of European Ceramic Society. Vol. 20, 2000. pp.1915-1921

[17] W. D. Kingery, H. K. Bowen, D. R. Uhlmann: Introduction to Ceramics. John Wiley \& Sons, New York, 1976. 